\title{
Alice in prognoseland : over de zin van arbeidsmarktprognoses
}

Citation for published version (APA):

Borghans, L., Heijke, J. A. M., \& de Grip, A. (2000). Alice in prognoseland : over de zin van

arbeidsmarktprognoses. Researchcentrum voor Onderwijs en Arbeidsmarkt, Faculteit der Economische Wetenschappen. ROA Working Papers No. 6 https://doi.org/10.26481/umarow.2000006

Document status and date:

Published: 01/01/2000

DOI:

10.26481/umarow.2000006

Document Version:

Publisher's PDF, also known as Version of record

\section{Please check the document version of this publication:}

- A submitted manuscript is the version of the article upon submission and before peer-review. There can be important differences between the submitted version and the official published version of record.

People interested in the research are advised to contact the author for the final version of the publication, or visit the DOI to the publisher's website.

- The final author version and the galley proof are versions of the publication after peer review.

- The final published version features the final layout of the paper including the volume, issue and page numbers.

Link to publication

\footnotetext{
General rights rights.

- You may freely distribute the URL identifying the publication in the public portal. please follow below link for the End User Agreement:

www.umlib.nl/taverne-license

Take down policy

If you believe that this document breaches copyright please contact us at:

repository@maastrichtuniversity.nl

providing details and we will investigate your claim.
}

Copyright and moral rights for the publications made accessible in the public portal are retained by the authors and/or other copyright owners and it is a condition of accessing publications that users recognise and abide by the legal requirements associated with these

- Users may download and print one copy of any publication from the public portal for the purpose of private study or research.

- You may not further distribute the material or use it for any profit-making activity or commercial gain

If the publication is distributed under the terms of Article $25 \mathrm{fa}$ of the Dutch Copyright Act, indicated by the "Taverne" license above, 


\title{
Alice in prognoseland Over de zin van arbeidsmarktprognoses
}

\author{
ROA-W-2000/6
}

Lex Borghans, Andries de Grip, Hans Heijke

"So you made some educational forecasts?" said the Tortoise. "Even though it does consist of an infinite series of problems and objections? I thought some wiseacre or other had proved that the thing couldn't be done?" "It can be done," said Achilles. "It has been done! Solvitur agendo. You see the problems and objections were constantly diminishing: and so...".

[Vrij naar Lewis Carroll, What the Tortoise said to Achilles, 1894]

\section{Researchcentrum voor Onderwijs en Arbeidsmarkt}

Faculteit der Economische Wetenschappen en Bedrijfskunde

Universiteit Maastricht

Maastricht, augustus 2000 
ISBN 90-5321-294-9

Sec00164/AdG 


\section{Inhoud}

1 Doel en opzet van de arbeidsmarktprognoses 1

1.1 Het doel van de prognoses 1

1.2 Globale opzet prognosemodel 2

1.3 Aandacht voor marktwerking 4

$\begin{array}{ll}1.4 \text { Aandacht voor kwaliteit van de prognoses } & 6\end{array}$

2 Verwachte arbeidsmarktontwikkelingen 1997-2002 8

2.1 Arbeidsmarktperspectieven schoolverlaters 8

$\begin{array}{ll}2.2 \text { Scholing } & 10\end{array}$

2.3 Oorzaken van de verwachte verkrapping van de arbeidsmarkt 11

3 Onzekerheid 12

3.1 Tegenvallende macro-economische ontwikkeling 12

3.2 Voorspellen 'trendbreuken' 13

3.3 Onzekerheidsmarges 14

4 Besluit $\quad 17$

$\begin{array}{ll}\text { Literatuur } & 17\end{array}$

Bijlage De Volkskrant 1995 



\section{Voorwoord}

In 1995 bracht het ROA prognoses naar buiten die erop wezen dat zich de komende jaren een opmerkelijke omslag op de arbeidsmarkt voor hoger opgeleiden zou voltrekken. Op grond van de ervaringen van de laatste twee decennia was destijds het beeld ontstaan van grote groepen afgestudeerden van met name de universiteiten die grote moeite hadden om een baan te vinden en vaak werk kregen waarvoor geen academische opleiding vereist was. Door op systematische wijze vraag- en aanbodontwikkelingen per opleidingstype naast elkaar te zetten, liet De arbeidsmarkt naar opleiding en beroep tot 2000 echter zien, dat voor een groot aantal opleidingen in het hoger onderwijs in de periode tot 2000 een einde zou komen aan dit sombere perspectief voor afgestudeerden. Ook in latere prognosestudies tot 2002, 2004 en 2007 worden weer aanwijzingen gevonden voor gunstige arbeidsmarktperspectieven voor hoger opgeleiden.

Inmiddels zijn we al gewend aan dit beeld van de veelgevraagde hoger opgeleiden en is in de media het zicht op dit verbeterde perspectief voor hoger opgeleiden verdrongen door het beeld van werkgevers die kampen met problemen en knelpunten doordat zij niet meer aan hoger opgeleide medewerkers kunnen komen. Uiteraard wil ook de Minister van Onderwijs, Cultuur en Wetenschappen zich bezinnen op een dergelijke sterke verandering in het beeld van de arbeidsmarktpositie van hoger opgeleiden. Ten behoeve van het Hoger Onderwijs en Onderzoek Plan 2000 (HOOP 2000) heeft het Ministerie van Onderwijs, Cultuur en Wetenschappen daarom aan de Stichting Economisch Onderzoek (SEO) en SCHOLAR (beide verbonden aan de Universiteit van Amsterdam) een 'second-opinion' gevraagd over de arbeidsmarktprognoses van het ROA' ${ }^{1}$. Het ROA is door het Ministerie gevraagd op deze beide notities te reageren.

Het is overigens alles behalve eenvoudig om in te zien wat de betekenis is van knelpunten op de arbeidsmarkt. In de media en het beleid wordt vaak de suggestie van een naderende ramp gewekt. De beide 'second-opinion' papers weerspiegelen daarentegen de visie van veel economen die geneigd zijn de gevolgen van de verwachte verschuivingen in vraag en aanbod als onbeduidend ter zijde te schuiven omdat de markt toch wel zijn werk zal doen. Beide visies kunnen gezien worden als een ideaaltypisch extreem. De ene groep gaat er ten onrechte van uit dat alle maatschappelijke verschuivingen met beleid moeten worden opgevangen en negeert het aanpassingsvermogen van de vele participanten op de arbeidsmarkt en daarmee iedere vorm van marktwerking. De andere groep lijkt daarentegen heilig in die marktwerking te geloven en vergeet dat volgens de studieboekjes niet alleen volledige mededinging, maar ook transparantie van de markt een voorwaarde is voor een optimaal aanpassingsproces. De waarheid ligt dus in het midden.

In de beide 'second opinion' papers wordt een aantal belangrijke kanttekeningen gemaakt bij de prognoses van het ROA. "Het belangrijkste knelpunt is dat 'in essentie' de inzichten uit de

1. Zie P.H.G. Berkhout en J.J.M. Theeuwes, (1999) en W. Groot en H. Maassen van den Brink, (1999). 
economische wetenschap in de modellen van het ROA ontbreken. Hierdoor vindt een systematische overschatting plaats van de knelpunten op de arbeidsmarkt. Met aanpassingsmechanismen tussen vraag en aanbod wordt geen rekening gehouden" (Groot en Maassen van den Brink, 1999).

Deze kritiek doet onze aanpak geen recht en laat ook zien dat er nog heel misverstanden zijn over de wijze waarop onze prognoses van de ontwikkelingen op de arbeidsmarkt worden gemodelleerd. Hoewel in de rapportages steeds uitvoerig wordt ingegaan op aanpassingsprocessen op de arbeidsmarkt manifesteert dit misverstand zich ook bij verschillende gebruikers van onze arbeidsmarktprognoses. Zo wordt bijvoorbeeld in het SER Advies HOOP 2000 geen gebruik gemaakt van onze indicatoren van de knelpunten op de arbeidsmarkt, maar een simpele optel- en aftreksom gemaakt van de onderliggende volume prognoses, om op die manier aan te geven hoeveel mensen met een bepaalde opleidingsachtergrond er over 5 jaar precies tekort komen. Dit suggereert inderdaad een rigide arbeidsmarkt waarbij knelpunten alleen opgelost worden als de tekorten door het beleid worden aangevuld.

Het leek ons om die reden belangrijk om nog eens duidelijk aan te geven wat de intentie en de daaraan gerelateerde opzet van de ROA-prognoses zijn. Om die reden hebben we in dit werkdocument de notitie waarin we vorig jaar op de beide 'second-opinion papers' reageerden omgezet in een zelfstandig leesbaar werkdocument. Om zoveel mogelijk aan te sluiten bij de destijds gevoerde discussie, waarin onze arbeidsmarktprognoses voor de periode 1997-2002 centraal stonden, zullen we hier ook ingaan op deze prognoses en hun beleidsimplicaties ${ }^{2}$.

De opzet in dit werkdocument is als volgt. In paragraaf 1 zal worden ingegaan op het doel van de ROA-prognoses en de daaruit voortvloeiende opzet van de prognose. In aansluiting hierop, zal in paragraaf 2 een beeld worden geschetst van de verwachte arbeidsmarktperspectieven, verbijzonderd naar opleidingsniveau. Tevens zullen in deze paragraaf enkele beleidsimplicaties en de oorzaken van de verwachte verkrapping van de arbeidsmarkt voor hoger en middelbaar opgeleiden worden aangestipt. In paragraaf 3 zal worden ingegaan op de belangrijkste kritiek op de ROA-prognoses. Deze kritiek spitst zich, naast het veronderstelde negeren van de aanpassingsprocessen op de arbeidsmarkt, toe op de onzekerheid waaraan prognoses van de ontwikkelingen op de arbeidsmarkt onderhevig zijn. Deze onzekerheid heeft een aantal aspecten: de macro-economische ontwikkeling, het optreden van trendbreuken en het moeten inbouwen van onzekerheidsmarges of schetsen van verschillende toekomstscenario's. Ten slotte worden in paragraaf 4 enkele concluderende opmerkingen gemaakt.

2. Nadien zijn door ons nieuwe arbeidsmarktprognoses opgesteld voor de periode 1999-2004. Zie ROA, (1999). 


\section{Doel en opzet van de arbeidsmarktprognoses}

\subsection{Het doel van de prognoses}

Het Researchcentrum voor Onderwijs en Arbeidsmarkt (ROA) stelt vanaf het eind van de jaren tachtig om de twee jaar prognoses op van de ontwikkelingen over vijf jaar in de vraag naar en het aanbod van arbeid per opleidingstype. Hieruit worden per opleidingstype de arbeidsmarktvooruitzichten voor nieuwkomers en de verwachte arbeidsmarktknelpunten voor werkgevers afgeleid. Doel van deze prognoses is dat degenen die betrokken zijn bij beslissingen over onderwijs kunnen anticiperen op de arbeidsmarktverschuivingen die naar verwachting zullen optreden. Studiekiezers kunnen de informatie benutten voor hun studiekeuze, bedrijven voor hun personeelsvoorziening en de overheid en intermediairs op de arbeidsmarkt, zoals Arbeidsvoorziening, kunnen in hun beleid inspelen op deze ontwikkelingen.

Het primaire doel van de prognoses is derhalve het transparant maken van de arbeidsmarkt, zodat leerlingen en bedrijven weten wat ze voor de komende jaren kunnen verwachten en hiernaar kunnen handelen. Zoals we in het inleidende citaat aangaven "It has been done". Zo wist het ROA door zijn gedifferentieerde aanpak reeds in de eerste helft van de jaren '90 'in strijd met de toenmalige tijdgeest' de omslag op de arbeidsmarkt te voorspellen voor enkele studierichtingen in het hoger onderwijs en het middelbaar beroepsonderwijs. Het bijgevoegde Volkskrant artikel is hiervan een duidelijke illustratie.

Doordat de ROA prognoses zich richten op de onderliggende vraag- en aanbodontwikkelingen op de arbeidsmarkt (uitbreidingsvraag, vervangingsvraag en arbeidsmarktinstroom nieuwkomers) kan wel degelijk een 'trendbreuk' in de arbeidsmarktperspectieven worden voorspeld. De toekomstige perspectieven voor schoolverlaters en de verwachte knelpunten in de personeelsvoorziening geven voor de betrokkenen aan wat de arbeidsmarkt voor hen in petto heeft. Dit betekent niet dat de prognoses voorschrijven wat leerlingen en bedrijven moeten doen. Het streven is ook niet dat alle leerlingen voor de opleiding met de beste perspectieven kiezen, maar dat leerlingen in hun studiekeuze een evenwichtige afweging kunnen maken op basis van hun interesses, capaciteiten en mogelijkheden op de arbeidsmarkt. Uit de door het ROA gegenereerde arbeidsmarktinformatie kan dus niet onmiddellijk de vereiste studiekeuze worden gehaald. Dit blijft een afwegingsproces van het individu. Hetzelfde geldt voor het overheidsbeleid. Onze prognoses geven aan hoe de situatie op de arbeidsmarkt zal veranderen. De geprognostiseerde knelpunten in de personeelsvoorziening voor bijvoorbeeld hoger opgeleiden betekenen dat werkgevers meer moeite zullen moeten gaan doen om deze categorie personeel te vinden en dat waarschijnlijk de kosten van hoger geschoolde arbeid (loonkosten, maar ook in de secundaire sfeer) zullen stijgen. Welke consequenties de overheid hieraan zou moeten verbinden voor haar beleid is op grond hiervan niet onmiddellijk vast te stellen, maar vergt 
een aanvullende analyse en afweging van de mogelijkheden die de overheid heeft in het licht van haar doelstellingen ${ }^{3}$.

Enkele decennia geleden is veel kritiek ontstaan op econometrische modellen en de mogelijkheid om op modeluitkomsten beleid te baseren. Dit wordt doorgaans aangeduid als de Lucas-kritiek (Lucas, 1976). De clou van deze kritiek is dat mensen in hun gedrag altijd zullen reageren op de omstandigheden en zullen proberen keuzes te maken die gegeven deze omstandigheden zoveel mogelijk in hun voordeel zijn. Econometrische beleidsmodellen die ervan uitgaan dat mensen zich blijven gedragen zoals ze zich in het verleden hebben gedragen, zullen daarom een veel te optimistisch beeld geven van de mogelijkheden voor de overheid om in te grijpen. Zoals hierboven is aangegeven, is het primaire doel van het ROA-model echter niet om beleidsanalyses te maken, maar om de arbeidsmarkt transparant te maken. Daarnaast zijn de ROA modellen juist gebaseerd op de gedachte dat economische agenten reageren op de veranderende omstandigheden. In die zin doorstaat het model dus de Lucas-kritiek. Lucas veronderstelt overigens dat mensen werkelijk optimaal reageren. Dit heet in economenjargon 'rationele verwachtingen'. Als er in de werkelijkheid ook sprake zou zijn van rationele verwachtingen, dan zouden de ROA-prognoses nutteloos zijn (zie ook Borghans, 1993a). ledereen zou immers ook zonder onze prognoses reeds alle arbeidsmarktontwikkelingen voorzien. Basisgedachte achter de ROA-prognoses is echter dat mensen weliswaar nastreven om een goede keuze te maken, maar dat zij daarbij een onvolledig beeld van de arbeidsmarkt hebben. Borghans (1993b) laat in zijn proefschrift zien dat in een dergelijke situatie prognoses - als ze verspreid worden bij de doelgroep - een bijdrage zullen leveren aan het functioneren van de arbeidsmarkt, zelfs zonder dat er enige beleidsmaatregel op basis van de prognoses wordt genomen.

\subsection{Globale opzet prognosemodel}

De prognoses van het arbeidsmarktperspectief voor de verschillende opleidingstypen zijn opgebouwd uit zes componenten. Aan de vraagkant betreft dit (1) de uitbreidingsvraag en (2) de vervangingsvraag. Aan de aanbodkant gaat het om (3) de instroom van schoolverlaters op de arbeidsmarkt, (4) de doorstroom naar het niet-reguliere onderwijs en (5) om het aanbod van kortdurig werklozen aan het begin van de prognoseperiode. Omdat de arbeidsmarkt van een opleidingstype geen afgesloten beroependomein heeft, wordt ten slotte ook rekening gehouden met (6) het substitutie-effect, dat de additionele vraag naar een opleidingstype aangeeft ten gevolge van de discrepanties tussen vraag en aanbod bij de andere opleidingen. Dit substitutie-effect kan uiteraard ook negatief zijn. Dit is het geval wanneer mensen met een bepaalde opleidingsachtergrond door een aanbodoverschot bij andere opleidingen, geconfronteerd worden met een geringere vraag.

3. Ook andere onderzoeksinstituten als het BLS (Verenigde Staten), COPS (Canada), IER (Verenigd Koninkrijk), ESRI (lerland) en IAB (Duitsland) hebben de 'manpower planning' benadering al lang achter zich gelaten (Een overzicht hiervan is te vinden in OECD, 1994 en Heijke, 1994.). 
Door de verwachte vraag- en aanbodstromen met elkaar te confronteren wordt per opleidingstype een indicatie verkregen van de toekomstige arbeidsmarktperspectieven voor nieuwkomers. Deze indicatie is dus met name van belang voor het onderwijs (studiekiezers en opleidingen). De desbetreffende indicator (de ITA) geeft aan welke vraag-aanboddiscrepantie er per opleidingstype te verwachten is. Een aanbodoverschot bij een bepaald opleidingstype impliceert echter niet vanzelfsprekend dat degenen met deze opleidingsachtergrond werkloos zullen worden. Omgekeerd betekent een voorspeld aanbodtekort niet automatisch dat er sprake zal zijn van onvervulde vacatures. Het is immers ook mogelijk dat werkgevers bij een aanbodoverschot van hoger opgeleiden, in bepaalde functies hun eisen aanpassen en mensen aannemen met een hogere opleidingsachtergrond dan aanvankelijk gevraagd werd. Schoolverlaters met een opleiding waarvoor het aanbod de vraag overtreft ervaren in een dergelijke situatie een verslechtering van hun positie doordat zij bijvoorbeeld vaker beneden hun niveau moeten werken, een minder goed contract krijgen, slechter beloond worden of vaker genoegen moeten nemen met parttime werk, terwij men liever een fulltime betrekking had. Omgekeerd zal bij een tekortschietend aanbod de positie van de desbetreffende categorie schoolverlaters verbeteren. Deze hoeven in dat geval minder vaak genoegen te nemen met onvrijwillig deeltijdwerk, een lagere beloning, enz. Voor sommige werkgevers wordt het aantrekken van mensen met deze opleidingsachtergrond hierdoor te duur. Zij zullen hierdoor misschien iemand gaan aantrekken met een andere opleidingsachtergrond, of blijven zitten met een onvervulde vacature.

Bij de opleidingen die door opleidingstypen met een aanbodoverschot worden verdrongen, zal het aantal beschikbare baanopeningen vanwege dit substitutieproces kleiner worden. Daarentegen zal er voor de opleidingen die verwant zijn aan de opleidingen met een tekortschietend aanbod juist sprake zijn van extra baanopeningen. Deze 'passieve' substitutie-effecten zijn derhalve van belang voor de arbeidsmarktperspectieven van de desbetreffende opleidingen.

Om ook een indicatie te kunnen geven van de mogelijke toekomstige wervingsproblemen waarmee werkgevers te kampen krijgen is per opleidingstype een Indicator van de Toekomstige Knelpunten in de Personeelsvoorziening (ITKP) gemaakt. Net als bij een ongunstig arbeidsmarktperspectief voor nieuwkomers op de arbeidsmarkt niet automatisch moet worden gedacht aan hoge werkloosheid, moeten knelpunten in de personeelsvoorziening, zoals reeds eerder is opgemerkt, niet zonder meer gelijk worden gesteld met de aanwezigheid van onvervulbare vacatures. Bedrijven kunnen immers op verschillende manieren op deze knelpunten inspelen: het bieden van een hogere beloning, het verbeteren van het imago, arbeidskrachten met een andere opleidingsachtergrond aantrekken, overwerk, e.d. Knelpunten in de personeelsvoorziening wijzen daarom in de eerste plaats op een toename van de door een bedrijf te maken kosten of te plegen inspanning als men een werkende uit het desbetreffende opleidingstype in dienst zou willen nemen. 


\subsection{Aandacht voor marktwerking}

Groot en Maassen van den Brink (1999) stellen dat de ROA-prognoses de knelpunten op de arbeidsmarkt onderschatten, omdat ze geen rekening houden met het aanpassingsmechanisme tussen vraag en aanbod. Zoals hierboven reeds is aangegeven is deze kritiek niet terecht. De misvatting op dit punt van Groot en Maassen van den Brink is waarschijnlijk toe te schrijven aan het ontbreken van lonen in de ROA-prognosemodellen. Uit analyses van de door het ROA opgezette grootschalige schoolverlatersenquêtes is ons echter duidelijk geworden dat economen zich wat al te eenzijdig concentreren op de loonontwikkeling als enige aanpassingsmechanisme. Andere aanpassingsmechanismen aan de aanbodzijde van de arbeidsmarkt zijn bijvoorbeeld: de mate waarin men bereid is werk te accepteren op een lager niveau, de mate waarin men werk vindt buiten de eigen vakrichting, het accepteren van tijdelijk werk en (onvrijwillig) deeltijdwerk en het kiezen van een vervolgopleiding in plaats van zich aan te bieden op de arbeidsmarkt. Ook de actoren aan de vraagzijde van de arbeidsmarkt kennen, zoals hierboven reeds werd opgesomd een groot aantal aanpassingsmogelijkheden (zie ook De Grip e.a., 1999).

Het ROA besteed veel aandacht aan de mogelijke substitutieprocessen op de arbeidsmarkt. Zo is bij zowel de gehanteerde beroepen- als opleidingenindeling gezocht naar indelingscategorieën die vanuit arbeidsmarktoogpunt relatief homogeen zijn (zie De Grip e.a., 1991 en Heijke e.a., 1998). Dit heeft als belangrijk voordeel dat opleidingen die onderling sterk substitueerbaar zijn binnen één opleidingstype zijn verenigd. Bovendien wordt in het door het ROA ontwikkelde prognosemodel, zoals hierboven reeds is opgemerkt, expliciet rekening gehouden met de substitutievraag tussen de verschillende opleidingstypen. Dit maakt het mogelijk om aan te geven in hoeverre de knelpunten op de arbeidsmarkt er bijvoorbeeld toe leiden dat mensen met een bepaalde opleidingsachtergrond zich weer terugtrekken op hun vakspecifieke segment of juist niet. In De Grip e.a. (1998) is dit voor de arbeidsmarkt van hoger opgeleiden uitgewerkt op basis van onze prognoses voor de periode 1995-2000.

Bij de ROA-prognoses wordt bij het modelleren van de substitutieprocessen onderscheid gemaakt tussen de zogenaamde ex ante veranderingen in vraag en aanbod, die los staan van de situatie op de arbeidsmarkt, i.c. de verschuivingen van vraag- en aanbodcurven, en de 'ex post' aanpassingsprocessen die juist een gevolg zijn van de situatie op de arbeidsmarkt en derhalve de verschuivingen langs de vraag- en aanbodcurven weerspiegelen (zie bv. Borghans en Heijke, 1996 en De Grip en Heijke, 1998). De prognoses laten zien hoe vraag en aanbod zich tot elkaar zouden verhouden als de situatie op de arbeidsmarkt van de verschillende opleidingen niet zou wijzigen. Het gaat dus om hypothetische vraag- en aanbodprognoses, waarbij het gedrag van werkgevers en werknemers is gebaseerd op de veronderstelling dat er geen veranderingen optreden in de 'beloning' op de arbeidsmarkt. Dit betekent echter niet dat de arbeidsmarkt in werkelijkheid ook niet zal reageren. De confrontatie van vraag en aanbod in een dergelijke aanpak levert echter een indicator op van de mate waarin de arbeidsmarkt zal moeten reageren om vraag en aanbod weer in evenwicht te brengen. Deze aanpassing hoeft echter niet altijd via de lonen te verlopen. Zoals reeds is opgemerkt kunnen ook andere aspecten van een baan worden aangepast om 
daarmee de baan meer of minder aantrekkelijk te maken. Een andere mogelijkheid is dat werkgevers hun zoekinspanningen verhogen of via bijscholing in hun personeelsbehoefte voorzien (zie voor het tweede Van Eijs en Heijke, 2000). Ook is het denkbaar dat de aanpassing die het gevolg is van een ex ante discrepantie tussen vraag en aanbod niet volledig is en dus deels ook in werkloosheid of onvervulde vacatures resulteert. Het model houdt dus vele verschillende aanpassingsmogelijkheden open.

Het in de ROA modellen opgenomen substitutiemechanisme wordt dan ook gestuurd vanuit het bredere discrepantiebegrip dat wij hanteren (zie Borghans en Willems, 1998). Dit substitutiemechanisme reflecteert het totale aanpassingsproces, waarvan het loonmechanisme slechts onderdeel uitmaakt. De door het ROA ontwikkelde methodiek heeft, zoals gezegd, als belangrijk voordeel dat een duidelijk signaal wordt gegeven van de te verwachten arbeidsmarktperspectieven voor schoolverlaters en de verwachte knelpunten in de personeelsvoorziening voor werkgevers.

Dit is een belangrijk verschil met het eenvoudige economische model waarin de arbeidsmarkt vanzelf in evenwicht is en het aanpassingsmechanisme altijd via de lonen verloopt. De idee achter onze benadering is dat het juist van belang is om de aanbod- en de vraagzijde van de arbeidsmarkt en de beleidsmakers te informeren over de verwachte situatie op de arbeidsmarkt, zodat zij hierop kunnen anticiperen. Ook als het loonmechanisme volledig werkt zal het slechts de verdeling van het bestaande aanbod van mensen met een bepaalde opleidingsachtergrond over de vraag reguleren. Als er bijvoorbeeld weinig mensen met een informatieopleiding beschikbaar zijn zal hun loon omhoog schieten om zo evenwicht tussen vraag en aanbod te bewerkstelligen. Als tijdig duidelijk was geweest dat de vraag naar mensen met deze opleidingsachtergrond toe zou nemen, zouden waarschijnlijk meer leerlingen deze studie zijn gaan doen en was de salarisverhoging die nodig is om de markt in evenwicht te krijgen minder hoog geweest. Borghans (1993b) laat zien dat aanpassingen achteraf altijd hogere maatschappelijke kosten met zich meebrengen.

Ook voor het beleid is het van belang om tijdig geïnformeerd te zijn over verschuivingen op de arbeidsmarkt ${ }^{4}$. Zo is het bijvoorbeeld van belang de overheid, in haar rol als werkgever, te informeren over de verwachte knelpunten in de personeelsvoorziening voor leerkrachten of medici. Een dergelijk signaal maakt het immers mogelijk tijdig maatregelen te treffen om de verwachte knelpunten te voorkomen. De wijze waarop het aanpassingsproces verloopt kan dus op basis van de gegeven informatie bijtijds beïnvloed worden. Op deze wijze kan bijvoorbeeld de betekenis van het bij- of omscholen van het arbeidsaanbod met slechtere arbeidsmarktperspectieven om te voorkomen dat werkgevers via hoge lonen om personeel moeten concurreren duidelijk onder de aandacht worden gebracht. De traditionele econo-

4. De marktmechanismen die in de vorige paragraaf beschreven staan vormen een ingewikkeld stelsel van elkaar wederzijds beïnvloedende grootheden. Het is een illusie om te denken dat er een model gemaakt kan worden dat tot in de kleinste details al deze samenhangen in beeld kan brengen. Om tot goede prognoses te komen is het daarom van belang dat het model de elementen bevat die er echt toe doen. 
mische benadering zou er daarentegen eenvoudig van zijn uitgegaan dat de arbeidsmarkt 'in the long run' vanzelf wel weer in evenwicht komt. Deze benadering heeft dus als belangrijk nadeel dat de (maatschappelijke) kosten van het aanpassingsgedrag van werkzoekenden en werkgevers en het eventueel te voeren overheidsbeleid daardoor buiten beeld blijven.

Ook voor werkgevers is het belangrijk om vroegtijdig informatie te hebben over de verwachte knelpunten op de arbeidsmarkt. Werkgevers staan bij een verwacht knelpunt in de personeelsvoorziening immers voor de keuze om hierop al dan niet te anticiperen door bijvoorbeeld het bij- of omscholen van arbeidskrachten met een matig of slecht arbeidsmarktperspectief. Als zij niet tijdig anticiperen op het knelpunt rest hen mogelijk niets anders dan om in een gevecht met andere werkgevers de lonen tegen elkaar op te bieden om zo het gewenste personeel binnen te halen. Hierdoor zal een deel van de werkgevers uit de markt worden geprijsd. Ook dan past de markt zich aan aan de nieuwe schaarsteverhoudingen, maar de kosten ervan zullen veel hoger zijn. Wanneer de concurrentiespiraal zich over de hele arbeidsmarkt uitstrekt, spreekt men wel van een 'loonexplosie'.

In onze middellange-termijnprognoses wordt de verwachte arbeidsmarktsituatie dan ook niet beschreven in termen van de verwachte werkloosheid of het verwachte tekort. In plaats daarvan wordt aan de studiekiezers een signaal gegeven van de verwachte 'toekomstige arbeidsmarktperspectieven' van de verschillende opleidingen en aan de werkgevers een signaal van de 'toekomstige knelpunten in de personeelsvoorziening'. Op welke wijze deze perspectieven en knelpunten zich zullen manifesteren in bepaalde aanpassingsvormen wordt daarbij in eerste instantie impliciet gelaten. In hoofdstuk 4 van De arbeidsmarkt naar opleiding en beroep tot 2002 wordt uitvoerig ingegaan op de mogelijke gevolgen van discrepanties tussen vraag en aanbod. Hierbij wordt een beeld gegeven van de aanpassingsmechanismen die te verwachten zijn en van de structurele aanpassingen en mogelijkheden voor beleid die de veranderingen op de arbeidsmarkt bieden ${ }^{5}$. Daarbij wordt bijvoorbeeld aangegeven in hoeverre het inzetten van langdurig werklozen of niet-participerenden met de juiste opleidingsachtergrond het mogelijk maakt de verwachte knelpunten in de personeelsvoorziening te voorkomen.

\subsection{Aandacht voor kwaliteit van de prognoses}

Om de kwaliteit van de prognoses te beoordelen is het daarom van belang niet alleen te kijken naar het elke twee jaar uitgebrachte rapport, maar is ook het proces waarbinnen deze prognoses tot stand komen van cruciale betekenis. Van belang is echter dat de onderzoekers steeds op zoek zijn naar de zwakke punten van de modellen en op basis hiervan voortdurend werken aan de verdere verbetering van de methodiek. Een deel van de beperkingen van het model wordt gevormd door de beschikbare data. Ook op dit front wordt daarom voortdurend gewerkt aan verbetering. Prioriteit bij de verdere ontwikkeling moet

5. In De arbeidsmarkt naar opleiding en beroep tot 2004 wordt voor verschillende opleidingstypen aangegeven welke aanpassingsprocessen op het desbetreffende arbeidsmarktsegment naar verwachting zullen optreden. 
uiteraard liggen bij die aspecten van het model die de meeste consequenties voor de kwaliteit van de prognoses hebben. Het model bevat daarom een aantal vereenvoudigende aannames waarvan inmiddels bekend is dat de impact daarvan niet groot is. Daarnaast zijn er ook expliciete of impliciete veronderstellingen die wel cruciaal zijn en dus om verder onderzoek vragen. Verder is ook van belang dat methodes worden gekozen die robuust zijn, d.w.z. niet sterk afhangen van een specifieke veronderstelling. Juist onze aanpak om vraag en aanbod tegenover elkaar te zetten is, zoals reeds is aangegeven, robuuster dan een loonmodel.

Verder is het van belang dat de prognoses en de methodiek aan voortdurende toetsing onderhevig zijn. Dit gebeurt op verschillende manieren:

1) Zeer belangrijk voor de kwaliteit van de arbeidsmarktprognoses is ook de systematische evaluatie van de prognoses (zie bv. Borghans e.a., 1994 en Borghans e.a., 1996, Smits e.a., 2000). Deze evaluatie-studies geven op de eerste plaats inzicht in de kwaliteit en de betrouwbaarheid van de door het ROA gemaakte arbeidsmarktprognoses. Daarnaast leveren de evaluatie-studies nieuwe inzichten op in de bruikbaarheid van de gehanteerde prognosemethodieken en de gemaakte aannames. Dit biedt vaak belangrijke aanknopingspunten voor verdere verbeteringen van de methodiek.

2) Onderzoeksresultaten worden gepresenteerd op congressen en gepubliceerd in tijdschriften. 'Peer reviews' die hieruit voortkomen zijn zeer nuttig als referentiekader van het onderzoek. Vanwege het specialisme van het onderzoek is het nodig de feedback internationaal te vergaren. Daarom zijn we lid van internationale netwerken van onderzoekers die vergelijkbaar onderzoek doen. Omdat we helaas moeten constateren dat in slechts weinig landen met ROA vergelijkbare instituten eenzelfde peil hebben bereikt in dit type onderzoek, breiden we deze netwerken meer en meer uit naar onderzoekers die zich bezighouden met verwante thema's. Anderen hebben dus eerder wat aan ons dan omgekeerd en we blijven voortdurend op zoek naar adequate wetenschappelijke feedback.

3) Op keuzes voor scenario's en groeicijfers kan men uiteraard in internationale kring weinig feedback verwachten. Doelbewust publiceren we daarom ook in Nederlandse beleidsgerichte bladen. De prognoses hebben bijvoorbeeld altijd in ESB gestaan en enkele jaren geleden heeft dit ook tot een gepubliceerde discussie geleid. Nederlandse onderzoekers die onze aanpak niet delen kunnen dus zeker van zich laten horen.

4) Daarnaast houdt het veld zich zeker niet stil, getuige het grote aantal telefoontjes als de prognoses in de publiciteit komen. Ook presenteert ROA de uitkomsten bij werkgeversorganisaties, Arbeidsvoorziening, de Sociaal Economische Raad, etc. Reacties van vertegenwoordigers van opleidingen en bedrijfstakken worden door het ROA zeer serieus onderzocht en op hun waarde beoordeeld. Afgelopen jaar heeft er bijvoorbeeld een uitvoerige discussie met vertegenwoordigers van de opleiding 'HBO personeel en organisatie' plaatsgevonden die in het blad PW Magazine zijn weerslag vond. 
5) Het ROA is weliswaar de enige in Nederland die dergelijke prognoses maakt, maar dat maakt ons nog niet tot een monopolist. Het onderzoek staat onder een voortdurende druk om het goed te doen om daarmee de continuïteit van het project te kunnen waarborgen. Bovendien wordt het onderzoek begeleid door een breed samengestelde begeleidingscommissie. Ten slotte geeft het zeer diverse gebruik van onze prognoses (getuige daarvan zijn telefoontjes van leerlingen en ouders, de pers, beleidsambtenaren, bedrijven, maar zelfs vanuit rechtszaken) een zwaar verantwoordelijkheidsgevoel om het goed te doen.

\section{Verwachte arbeidsmarktontwikkelingen 1997-2002}

\subsection{Arbeidsmarktperspectieven schoolverlaters}

Om de betekenis van onze prognosemethodiek te concretiseren is het interessant nader in te gaan op de prognoses die in 1997 zijn opgesteld voor de periode tot $2002^{6}$. De in 1995 door het ROA uitgebrachte prognoses voor de periode 1995-2000 wezen al in de richting van gunstige vooruitzichten voor met name het hoge onderwijs. Op grond van de daarna uitgebrachte arbeidsmarktprognoses voor de periode 1997-2002 mag verwacht worden dat deze ontwikkeling zich voortzet ${ }^{7}$. Bovendien verbeteren ook duidelijk de arbeidsmarktperspectieven van het MBO/Leerlingwezen en het HAVO/VWO.

Tabel 1

Percentage schoolverlaters met opleidingen waarvoor een slecht of matig arbeidsmarktperspectief wordt verwacht, per opleidingsniveau

Opleidingsniveau $\%$

$\begin{array}{lr}\text { Basisonderwijs } & 100,0 \\ \text { VBO, MAVO } & 21,5 \\ \text { MBO/LLW, HAVO/VWO } & 12,9 \\ \text { HBO } & 6,2 \\ \text { WO } & 1,7\end{array}$

Tabel 1 laat zien dat het percentage schoolverlaters met een opleidingstype met een slecht of matig arbeidsmarktperspectief, afneemt naarmate het opleidingsniveau hoger is. Schoolverlaters met uitsluitend basisonderwijs hebben matige arbeidsmarktperspectieven.

6. Hoewel er zoals eerder is aangegeven door ons in 1999 nieuwe prognoses zijn opgesteld voor de periode 1999-2004, richten we ons hier op prognoses voor de periode 1997-2002. Op deze wijze kan het beste worden aangesloten bij de destijds gevoerde discussie.

7. De oktober 1999 uitgebrachte prognoses voor de periode 1999-2004 wijzen eveneens op (zeer) goede arbeidsmarktperspectieven voor hoger opgeleiden. Dit ondanks het feit dat deze prognoses zijn gebaseerd op het behoedzame scenario van het Centraal Planbureau. 
Op VBO- en MAVO-niveau heeft ruim 20\% van de schoolverlaters een opleidingstype gevolgd met slechte of matige vooruitzichten op de arbeidsmarkt. Van de schoolverlaters op $\mathrm{MBO} / \mathrm{HAVO} / \mathrm{VWO}$-niveau zal circa $13 \%$ worden geconfronteerd met matige of slechte vooruitzichten. Vooral voor gediplomeerden van het opleidingstype MBO toerisme en recreatie zijn de vooruitzichten niet florissant. In mindere mate geldt dat voor de opleidingstypen MBO grafische techniek, bewegingstherapie, verzorging en MBO opleidingstypen die opleiden tot dokters-, tandarts- en dierenartsassistent. Zeer gunstige perspectieven zijn er op dit niveau voor degenen met een opleiding operationele techniek, procestechniek, gezondheidstechniek, verpleging en horeca.

Op HBO-niveau heeft slechts ongeveer $6 \%$ van de schoolverlaters een opleidingstype gevolgd dat, gelet op het arbeidsmarktperspectief, minder gunstig is. Dit betreft degenen die $\mathrm{HBO}$ personeelswerk of $\mathrm{HBO}$ milieukunde en levensmiddelentechnologie studeren. De HBO-opleidingstypen die een zeer gunstig vooruitzicht bieden zijn zeer divers: radiologie, landbouw en veeteelt, informatica, vervoer en logistiek, lerarenopleiding economie en maatschappij, recht en bestuur en bouwkunde.

Van de universitaire opgeleiden, ten slotte, hebben uitsluitend de kunstwetenschappers een matig perspectief op de arbeidsmarkt. Zij maken in de komende periode evenwel slechts $1,7 \%$ van de arbeidsmarktinstroom op WO-niveau uit. Ook op dit niveau biedt de opleiding bouwkunde zeer goede perspectieven op de arbeidsmarkt. Dit geldt eveneens voor de opleidingstypen civiele techniek, informatica en bestuurlijke informatiekunde, accountancy en belastingen, tandheelkunde en bedrijfskunde.

Zoals reeds is aangegeven, is het niet vanzelfsprekend dat deze knelpunten op de arbeidsmarkt leiden tot ingrijpen van de overheid. Studiekiezers, werknemers en werkgevers zullen reageren op de verschuivingen in vraag en aanbod, waardoor er een aanpassing aan de verwachte knelpunten op gang komt. Van primair belang is echter dat de markt in staat is om tijdig op deze veranderingen te reageren. Voor studiekiezers betekent dit bijvoorbeeld dat zij reeds voordat ze aan een studie beginnen een beeld moeten hebben van de arbeidsmarktontwikkelingen over een jaar of vier, als zij de opleiding afronden. Arbeidsmarktprognoses hebben daarom zelfs zonder expliciet overheidsingrijpen als publiek goed een duidelijke waarde. Overigens kan de overheid daar wel een bijdrage aan leveren door te stimuleren dat de studiekeuzevoorlichting jongeren helpt om in hun persoonlijke afweging ook arbeidsmarktaspecten een plaats te geven.

De overheid kan bovendien door haar beleid mogelijk richting geven aan de wijze waarop het aanpassingsproces plaatsvindt. Zij kan aanpassingen die vanuit maatschappelijk oogpunt meer gewenst zijn stimuleren en ongewenste ontwikkelingen, zoals een excessieve toename van de lonen vanwege de krapte op de arbeidsmarkt, afremmen. Het zou dan bij het overheidsbeleid niet (alleen) gaan om het 'oplossen van knelpunten', maar ook om het gebruik maken van de verwachte ontwikkelingen om zo mensen of bedrijven met een zwakke positie op de arbeidsmarkt te ondersteunen. Ten slotte zal de overheid, in haar rol als werkgever, met een belangrijk marktaandeel op bepaalde segmenten van de arbeids- 
markt, zelf ook vroegtijdig kunnen inspelen op de knelpunten op de arbeidsmarkt waarmee zij naar verwachting geconfronteerd wordt.

\subsection{Scholing}

Gezien de verwachte ontwikkelingen op de arbeidsmarkt ligt het voor de overheid voor de hand om - voorzover zij hier een taak ziet liggen - de her-, om- en bijscholing van werkenden, werkzoekenden en niet-participerenden te stimuleren. Vanwege de omvang van de voor de komende jaren verwachte knelpunten in de personeelsvoorziening, is het evident dat - ter voorkoming van productie-uitval of een mogelijke 'loonexplosie' - het bij- of omscholen van de mensen met opleidingen met een matig tot slecht arbeidsmarktperspectief een belangrijke bijdrage kan leveren aan het verwachte aanpassingsproces. Daarbij moet worden bedacht dat de grote knelpunten in de personeelsvoorziening zich vaak voordoen bij de hoger opgeleiden, terwijl de aanbodoverschotten zich concentreren bij de lager opgeleiden.

Een belangrijke doelgroep voor bij- of omscholing is de groep langdurig werklozen. Het is opmerkelijk dat bijna de helft van de langdurig werklozen een opleidingsachtergrond heeft met goede arbeidsmarktperspectieven. Het gaat hier om circa 110.000 personen. Voor een zestal opleidingen op vbo-, mbo-, of hbo-niveau zou het inzetten van een deel van de langdurig werklozen met de desbetreffende opleidingsachtergrond de verwachte aanbodtekorten in principe kunnen voorkomen. Uiteraard is het toepassen van het scholingsinstrument hierbij van belang omdat een groot deel van de langdurig werklozen waarschijnlijk niet direct inzetbaar is door kwalificatieverlies e.d.

Ook het verhogen van de arbeidsparticipatie zou een belangrijke bijdrage kunnen leveren aan het voorkomen van knelpunten. Voor eenderde van de opleidingstypen waarvoor grote tot zeer grote knelpunten in de personeelsvoorziening worden verwacht, zou echter - zonder aanvullende maatregelen zoals loonaanpassing, arbeidsduurverlenging, enz. - een volledige inzet van de niet-participerenden met een geschikte opleidingsachtergrond nog ontoereikend zijn om in de vraag te voorzien. Voor een aantal andere opleidingstypen zou de nonparticipatie enorm moeten worden teruggebracht. Zelfs dit laatste is waarschijnlijk al een moeilijk te realiseren doelstelling.

Ten slotte zou de aandacht kunnen uitgaan naar het vergroten van de arbeidsparticipatie van allochtone arbeidskrachten. Gezien hun opleiding bestaan er overigens grote verschillen in de inzetbaarheid van de diverse groepen allochtonen. Bij Turken en Marokkanen zal het verhogen van de arbeidsparticipatie waarschijnlijk de grootste beleidsinspanningen vergen. Daarentegen lijken allochtonen afkomstig uit het voormalige Joegoslavië, door hun relatief hoge opleidingsniveau, zeer goed inzetbaar te zijn op de arbeidsmarktsegmenten waarvoor de verwachte knelpunten in de personeelsvoorziening groot zijn. 


\subsection{Oorzaken van de verwachte verkrapping van de arbeidsmarkt}

De systematische opzet van het ROA-prognose model maakt het mogelijk nader te analyseren welke onderliggende vraag- en aanbodontwikkelingen ten grondslag liggen aan de verwachte knelpunten op de arbeidsmarkt voor veel hogere opleidingen (en opleidingen op MBO-niveau). In de eerste plaats kan daarbij gekeken worden naar de verwachte algehele ontwikkeling van vraag en aanbod op de arbeidsmarkt in de periode 1997-2002. Hierbij valt op dat - ten opzichte van de voorafgaande vijfjaarsperiode - zowel de aantrekkende uitbreidingsvraag (1,7\% gemiddeld per jaar), als de vanwege de vergrijzing van de werkzame bevolking toenemende vervangingsvraag (toename tot 3,3\% gemiddeld per jaar) en de dalende arbeidsmarktinstroom van schoolverlaters (afname tot $4,2 \%$ gemiddeld per jaar) een toenemende verkrapping op de arbeidsmarkt bewerkstelligen.

Wanneer er echter alleen gekeken wordt naar dit macrobeeld van de ontwikkelingen op de arbeidsmarkt, treedt er een grote onderschatting op van de dynamiek die zich op het niveau van de verschillende beroepsgroepen of opleidingstypen kan voordoen en de knelpunten die als gevolg daarvan kunnen optreden. Zo is de verwachte uitbreidingsvraag voor het opleidingstype WO informatica en bestuurlijke informatiekunde $(9,8 \%$ gemiddeld per jaar) maar liefst ruim het vijfvoudige van de verwachte gemiddelde werkgelegenheidsgroei. Daar tegenover staat bijvoorbeeld een werkgelegenheidskrimp voor degenen met alleen basisonderwijs van maar liefst 3,6\% gemiddeld per jaar. De in hoofdstuk 2 van De arbeidsmarkt naar opleiding en beroep tot 2002 gepresenteerde tabellen laten zien dat er ook bij de vervangingsvraag en vooral ook bij de arbeidsmarktinstroom van schoolverlaters grote verschillen zijn tussen de onderscheiden beroepsgroepen en opleidingstypen.

Met name economen hebben vaak te weinig oog voor de mogelijke knelpunten in de personeelsvoorziening die zich op dit relatief lage aggregatieniveau kunnen voordoen. Enerzijds is dit waarschijnlijk een gevolg van een sterke oriëntatie op de macro-economische ontwikkeling (i.c. de verwachte macro-economische werkgelegenheidsgroei). Anderzijds is er weinig aandacht voor de arbeidsmarktdiscrepanties op een lager aggregatieniveau, vanwege de impliciete aanname dat deze door de werking van de markt ('de loonaanpassingen') vanzelf wel weer zullen verdwijnen. Zoals reeds is opgemerkt, betekent een marktaanpassing echter nog niet dat de aanpassingen zonder kosten gepaard gaan.

Vanuit deze eenzijdige macro-oriëntatie is er ook onvoldoende aandacht voor de verschillende componenten van de werkgelegenheidsverschuivingen. Tabel 2 geeft hiervan een overzicht voor de opleidingen op het HBO- en WO-niveau. De tabel laat zien dat de verwachte uitbreidingsvraag naar WO'ers slechts voor ruim een derde is toe te schrijven aan de verwachte macro-economische werkgelegenheidsontwikkeling. De 'upgrading' van de vraag als gevolg van de verschuivingen in de beroepenstructuur (het 'beroepseffect') en de verschuivingen in de opleidingsstructuur binnen de beroepssegmenten (het 'opleidingseffect') is daarentegen veel belangrijker. Mede om deze reden heeft de doorrekening met een ander groeiscenario van de macro-economische werkgelegenheid slechts een beperkte invloed op de toekomstige werkgelegenheidsgroei. Voor het toekomstige arbeidsmarktperspectief is het effect van een ander groeiscenario nog geringer, vanwege de kwantitatief belangrijke rol van 
de vervangingsbehoefte bij het bepalen van het totaal aantal baanopeningen voor nieuwkomers.

Tabel 2

Componenten van de werkgelegenheidsverschuivingen voor HBO'ers en WO'ers*

\begin{tabular}{lcc}
\hline & $\begin{array}{c}\text { HBO } \\
\%\end{array}$ & $\begin{array}{c}\text { WO } \\
\%\end{array}$ \\
\hline Macro-economische werkgelegenheidsgroei & 8,8 & 8,8 \\
Bedrijfssectoreffect & 0,6 & 0,2 \\
Beroepseffect & 0,7 & 3,4 \\
Opleidingseffect & 7,0 & 7,3 \\
Passieve substitutie & 1,1 & 5,0 \\
Totaal & 17,1 & 24,6 \\
\hline * &
\end{tabular}

* Deze percentages hebben betrekking op de gehele periode 1997-2002

\section{Onzekerheid}

Prognoses gaan altijd gepaard met een zekere mate van onzekerheid. Het is daarom van belang in te gaan op de mogelijke invloed van onzekerheid op de prognose-uitkomsten en de wijze waarop de methodiek deze onzekerheid tracht te reduceren ${ }^{8}$. Onzekerheid heeft een drietal aspecten:

- de macro-economische ontwikkeling;

- het optreden van trendbreuken;

- het bestaan van bepaalde onzekerheidsmarges.

Op deze drie aspecten van de onzekerheid zal in deze paragraaf achtereenvolgens worden ingegaan.

\subsection{Tegenvallende macro-economische ontwikkeling}

Zowel Groot en Maassen van den Brink als Berkhout en Theeuwes bekritiseren de keuze van het gunstige groeiscenario van het CBP als uitgangspunt voor de ROA prognoses van de uitbreidingsvraag. Groot en Maassen van den Brink verwoorden dit als volgt: "In De arbeidsmarkt naar opleiding en beroep tot 2002 valt te lezen dat wordt gerekend met een toename van de werkgelegenheid in de desbetreffende periode van $1,7 \%$ per jaar. Dit is 0,3 procentpunten hoger dan de in de periode 1992-1996. Zowel in historisch perspectief als in internationaal werkgelegenheid opzicht is een gemiddelde werkgelegenheidsgroei van 1,7\% over een periode van vijf jaar uitzonderlijk hoog te noemen. Een gemiddelde werkgelegen-

8. Naast het veronderstelde ontbreken van de aanpassingsprocessen tussen vraag en aanbod op de arbeidsmarkt spitst de kritiek van Groot en Maassen van den Brink (1999) en Berkhout en Theeuwes (1999) zich toe op de onzekerheid van prognoses van vraag en aanbod. 
heidsgroei van minder dan $1 \%$ over een periode van vijf jaar lijkt ons realistischer" (Groot en Maassen van den Brink, pp.11-12).

Inderdaad is een gemiddelde werkgelegenheidsgroei van 1,7\% over een periode van vijf jaar uitzonderlijk hoog. De werkgelegenheidsontwikkeling van de afgelopen tijd toont echter het ongelijk van Groot en Maassen van den Brink. Bij het opstellen van de arbeidsmarktprognoses tot 2002 is door ons destijds voor het gunstige groeiscenario van het CPB gekozen, omdat de feitelijke economische ontwikkeling op dat moment zich reeds ver boven dit groeipad bevond en de verwachtingen voor de eerstkomende jaren zeer rooskleurig werden ingeschat. De eerste jaren van de prognoseperiode (1997-2002) is gebleken dat de werkgelegenheidsgroei nog hoger was dan de gemiddelde jaarlijkse groei van 1,7\% waarvan door ons is uitgegaan. In 1997 was de werkgelegenheidsgroei maar liefst 2,6\% en in 1998 zelfs $2,9 \%$. Zelfs als de werkgelegenheidsgroei de komende jaren wat af zal nemen, mag worden aangenomen dat de verwachte werkgelegenheidstoename van gemiddeld $1,7 \%$ per jaar over de periode 1997-2002 zeker niet een te optimistische inschatting is geweest.

De sterke groei van de werkgelegenheid die we de laatste jaren meemaken, illustreert ook dat het economisch adagium dat de arbeidsmarkt zich automatisch aanpast door het loonmechanisme niet zonder meer opgaat. Het blijft echter altijd moeilijk het groeitempo van de economie te voorzien. Het is ons inziens echter niet goed op basis van kort-cyclische schommelingen in de economische verwachtingen het op middellange termijn geprognosticeerde groeitempo in twijfel te trekken. Dit zou ook de signaalwerking die van de prognoses uitgaat aantasten. Aannemend dat iedereen weet dat toekomstvoorspellingen altijd aan enige onzekerheid onderhevig zijn, lijkt het ons voldoende om om de twee jaar met nieuwe prognoses te komen, waarin het verwachte groeitempo van de werkgelegenheid kan worden bijgesteld. Dit te meer daar, zoals tabel 2 aangeeft, de uitbreidingsvraag voor een bepaalde opleiding slechts voor een beperkt deel door de macro-economische ontwikkeling wordt beïnvloed.

\subsection{Voorspellen 'trendbreuken'}

Groot en Maassen van den Brink stellen dat de ROA prognoses niet verschillen van de inzichten die een algemene beschouwing van de arbeidsmarkt zou opleveren. Zij zijn zich er daarbij evenwel niet van bewust dat de in ons land aanwezige algemene beelden van de arbeidsmarkt in eerste instantie in belangrijke mate door de publicitaire activiteiten van het ROA zijn gevoed. Ook zijn wij een van de eersten geweest die op de implicaties van een oplopende spanning op de arbeidsmarkt hebben gewezen, met name voor de noodzaak de arbeidsmarktuitstroom te verminderen en het niet actieve aanbod te activeren. Bij het maatschappelijk debat over verschillende 'oplossingsmogelijkheden' voor de knelpunten op de arbeidsmarkt is dan ook vaak gebruik gemaakt van de in onze publicaties voorspelde arbeidsmarktperspectieven van bepaalde opleidingsrichtingen.

Een algemeen beeld van de arbeidsmarkt geeft echter nog onvoldoende houvast voor een prognose van de verschillende deelmarkten. Zoals in paragraaf 1.1 werd aangegeven wist 
het ROA door zijn gedifferentieerde aanpak reeds in de eerste helft van de jaren '90 'in strijd met de toenmalige tijdgeest' de omslag op de arbeidsmarkt te voorspellen voor enkele studierichtingen in het hoger onderwijs en het middelbaar beroepsonderwijs. Doordat de ROA prognoses zich richten op de onderliggende vraag- en aanbodontwikkelingen op de arbeidsmarkt (uitbreidingsvraag, vervangingsvraag en arbeidsmarktinstroom nieuwkomers) kan wel degelijk een 'trendbreuk' in de arbeidsmarktperspectieven worden voorspeld.

De door Groot en Maassen van den Brink gesuggereerde alternatieve methode gebaseerd op interviews met werkgevers en consumenten schiet juist op dit punt ernstig tekort ${ }^{9}$. In de eerste plaats is niet duidelijk wat het precieze doel van deze 'judgements forecasts' is. In analogie met de producenten- en consumentenvertrouwen indices zou het mogelijk enige betekenis kunnen hebben voor het voorspellen van de ontwikkelingen op de zeer korte termijn. Voor het prognosticeren van de (middel)lange termijn heeft een dergelijke aanpak geen enkele betekenis. Bovendien is er, in tegenstelling tot de bruikbaarheid van de producenten- en consumentenvertrouwen indices voor het voorspellen van de conjuncturele ontwikkeling, geen logische relatie tussen de verwachte kans op knelpunten op de arbeidsmarkt en het 'gedrag' dat tot dergelijke knelpunten kan leiden. Bovendien blijkt dat de voorspelkracht van deze prognosemethodiek gering is vanwege het feit dat men teveel gewicht geeft aan de actuele omstandigheden (McNees, 1990). We hebben het dan nog niet eens gehad over de enorme onderzoeksinspanning die nodig is om op basis van al deze interviews een volledig beeld van de arbeidsmarkt te maken dat consistent is en een hoog realiteitsgehalte heeft. Dit soort interviews kunnen hoogstens een aanvulling maar beslist geen substituut vormen voor een modelmatige aanpak.

\subsection{Onzekerheidsmarges}

Berkhout en Theeuwes (1999) concentreren hun kritiek met name op de statistische aspecten van de prognose-methodiek. Tegen hun kritische kanttekeningen bij de econometrische modelbouw in het algemeen - onvoorziene, structurele veranderingen in de economie worden niet meegenomen, het bestaand beleid van de overheid wordt als uitgangspunt genomen - valt natuurlijk niet veel in te brengen. Het is echter veeleer de vraag wat hier het alternatief is. Zoals hierboven reeds werd aangegeven zijn de meer kwalitatieve prognosesmethoden vaak niet meer dan uitvergrotingen van de actuele situatie en onvoorziene veranderingen zijn per definitie niet te voorspellen.

Gezien het primaire gebruiksdoel van de middellange termijn arbeidsmarktprognoses van het ROA, is het het meest doelmatig voor alle onderscheiden beroepen en opleidingen met één prognose-uitkomst te komen. Het presenteren van meerdere scenario-uitkomsten zou hier verwarrend werken. Bovendien zullen de kwalitatieve typeringen van de arbeidsmarkt-

9. Enkele jaren geleden is door ons onderzocht wat de mogelijkheden op dit punt zouden zijn. In Borghans e.a. (1994) wordt door ons uitvoerig ingegaan op de betekenis van het gebruik van kwalitatieve expertise. 
perspectieven van de diverse opleidingen indien men uitgaat van enigszins realistische scenario's op de middellange termijn, slechts in zeer beperkte mate uiteenlopen ${ }^{10}$.

Het ROA heeft er daarbij bewust voor gekozen aan te haken bij de middellange-termijnprognoses van het Centraal Planbureau en geen gebruik te maken van mogelijke alternatieve prognoses van bijvoorbeeld NYFER. Deze keuze is gebaseerd op een aantal overwegingen: (1) goede reputatie van het CPB, (2) transparantie van de gehanteerde methodiek en modelresultaten, (3) aandacht voor interne kwaliteitsbewaking en (4) onafhankelijkheid.

Naast deze middellange-termijnprognoses kan het met name vanuit beleidsoptiek waardevol zijn een scenariostudie met betrekking tot de lange-termijnontwikkelingen op te stellen, bijvoorbeeld om na te gaan wat de mogelijke effecten van bepaalde beleidsmaatregelen op de lange termijn zouden kunnen zijn. Vanwege de op de lange termijn veel grotere onzekerheden over structuurverschuivingen, omgevingsveranderingen e.d. is een scenario-analyse in dat geval doelmatig. Bovendien biedt een lange-termijnscenariostudie de mogelijkheid de implicaties van onderling sterk uiteenlopende consistente 'beleidspakketten' in beeld te brengen. Dit gebeurt eveneens in de lange-termijnscenario-studies van het CPB. In het verleden is door het ROA ook voortgebouwd op deze lange-termijn scenario's van het Centraal Planbureau. Voorbeelden hiervan zijn de Toekomstverkenning arbeidsmarkt zorgsector (De Grip e.a., 1994) en de Toekomstverkenning arbeidsmarkt en scholing tot 2007 (Borghans e.a., 1998). Een dergelijke aanpak zou ook voor de hand liggen bij een prognosestudie gericht op het analyseren van de behoefte aan hoger opgeleiden op de lange termijn.

Berkhout en Theeuwes gaan ook uitvoerig in op de geringe statistische betrouwbaarheid van de EBB-cijfers verbijzonderd naar het grote aantal beroepsgroepen en opleidingstypen dat in de ROA-prognoses wordt onderscheiden. Van deze problematiek zijn wij ons vanzelfsprekend van het begin af aan bewust geweest. Langs drie verschillende wegen wordt hierop ingespeeld, te weten:

- $\quad$ een efficiënt modelleringskader;

- het gebruik van Random-Coëfficiënt modellen;

- het geven van kwalitatieve typeringen.

In de eerste plaats vinden onze analyses niet op een zo laag desaggregatie niveau plaats als Berkhout en Theeuwes veronderstellen. Zo wordt bij de modellering van de uitbreidingsvraag naar beroepsklasse de sectorale werkgelegenheid niet verbijzonderd naar 123 beroepsgroepen, maar naar 43 beroepssegmenten. In een tweede stap worden deze werkgelegenheidsprognoses naar beroepssegment pas verbijzonderd naar beroepsgroep. In het laatste model wordt echter niet meer verbijzonderd naar bedrijfssector. Ook bij de prognoses

10. Hierbij moet worden bedacht dat de arbeidsmarktprognoses reeds in het kader van een veel bredere informatieverstrekking aan de actoren op de arbeidsmarkt en de beleidsinstanties worden gepresenteerd. De aanvulling met 'risico-indicatoren' met betrekking tot de conjunctuurgevoeligheid van de werkgelegenheid en de uitwijkmogelijkheden op de arbeidsmarkt is hiervan een duidelijk voorbeeld. 
van de uitbreidingsvraag naar opleidingstype wordt niet verbijzonderd naar bedrijfssector maar wordt direct aangehaakt bij de prognoses naar de 43 beroepssegmenten, dus niet bij de veel verder verbijzonderde prognoses naar beroepsklasse. Het aggregatieniveau van onze analyses van de EBB data ligt derhalve aanzienlijk hoger dan Berkhout en Theeuwes veronderstellen. Bovendien is de feitelijke celvulling in de beroep-opleiding matrix veel geconcentreerder dan door Berkhout en Theeuwes wordt verondersteld ${ }^{11}$.

Zoals hierboven reeds werd aangegeven, is het gebruik van Random-Coëfficiënt modellen een goede manier om gebruik te maken van de beschikbare informatie op een lager aggregatieniveau, zonder het gevaar te lopen dat de schattingsresultaten op te fragiele informatie zijn gestoeld. Wanneer de informatie op het lage aggregatieniveau door meetfouten een grotere instabiliteit vertoont zal de geschatte coëfficiënt meer naar de gemiddelde waarde van de coëfficiënt op een hoger aggregatieniveau tenderen. De betrouwbaarheid van de voorspellingen wordt in dat geval dus minder aangetast door het gebruik van 'onbetrouwbare' informatie op het laagste niveau van de analyse.

De derde manier waarop door ons geprobeerd wordt rekening te houden met de onzekerheid waarmee het opstellen van prognoses - ongeacht de gehanteerde methodiek gepaard gaat, is het 'vertalen' van de kwantitatieve prognoseresultaten in een kwalitatieve typering. Zo worden de prognoses van de toekomstige arbeidsmarktperspectieven voor schoolverlaters (ITA), op basis van een vijfpuntsschaal, uitgedrukt in termen van 'slechte' tot 'zeer goede' perspectieven ${ }^{12}$.

Zoals reeds eerder is aangegeven gaat het hier bovendien slechts om een indicatie van de verwachte spanning tussen vraag en aanbod op de arbeidsmarkt en niet om een voorspelling van de omvang van de werkloosheid of de te verwachten loonstijging. Op deze wijze ontstaat een belangrijke bandbreedte rondom de prognose-resultaten, terwijl de gegeven informatie toch een belangrijke signaalwerking heeft naar de studiekiezers, de actoren op de arbeidsmarkt en de beleidsmakers. Uit eerdere evaluatie-studies blijkt dat de voorspelkwaliteit van deze kwalitatieve typeringen zeer groot is (zie Borghans e.a., 1996). Wij schatten de beleidsmatig georiënteerde lezer van onze rapporten overigens voldoende hoog in om de betekenis van onze prognoses op zijn juiste waarde te kunnen schatten. Als men daarover meer inzicht zou willen verwerven kunnen wij verwijzen naar onze publiek beschikbare uitvoerige methodologische verantwoording en niets verbloemende evaluatiestudies (zie bv. Borghans e.a., 1996).

11. Berkhout en Theeuwes veronderstellen dat $10 \%$ van de matrix-elementen relevant is.

12. Op soortgelijke wijze wordt de Indicator van de toekomstige kans op knelpunten uitgedrukt op een vijfpuntsschaal uiteenlopend van 'vrijwel geen' tot 'zeer groot'. 


\section{Besluit}

We hebben in dit werkdocument geprobeerd de doelstellingen en de opzet van de arbeidsmarktprognoses van het ROA nog eens duidelijk aan te geven. Dit omdat Groot en Maassen van den Brink (1999) geen enkel oog lijken te hebben voor de wijze waarop onze aanpak zowel qua doelstelling als methodiek afwijkt van de enkele decennia achter ons liggende 'manpower planning'. Op deze wijze is ook getracht duidelijk te maken hoe belangrijk het is de ex ante discrepanties op de arbeidsmarkt voor de actoren op de arbeidsmarkt en de betrokkenen bij het onderwijs- en arbeidsmarktbeleid in beeld te brengen. Een dergelijk signaal maakt het mogelijk te anticiperen op deze knelpunten. De traditionele economische benadering, die door Groot en Maassen van den Brink (1999) en Berkhout en Theeuwes (1999) wordt bepleit gaat er daarentegen vanuit dat de arbeidsmarkt vanzelf wel weer in evenwicht komt door een 'aanpassing' van de lonen. De (maatschappelijke) kosten van het aanpassingsgedrag van werkgevers en werkzoekenden en het eventueel te voeren overheidsbeleid blijven daardoor buiten beschouwing. Uit analyses van de schoolverlatersonderzoeken blijkt bovendien dat economen zich wat al te eenzijdig concentreren op de loonontwikkeling als enig aanpassingsmechanisme.

\section{Literatuur}

Berkhout, P.H.G.B., J.J.M. Theeuwes (1999), Voorspellen op de arbeidsmarkt: Voetangels en valkuilen, Amsterdam.

Borghans, L. (1993a), Educational Choice and Labour Market Information, proefschrift Rijksuniversiteit Limburg, Maastricht.

Borghans, L. (1993b), 'Errors in Rational Expectations Matter', Economics Letters, Vol. 41, pp. 25-28.

Borghans, L., H. Heijke (1994), Een random-coëfficiëntenmodel voor het voorspellen van de beroepenstructuur van bedrijfstakken, ROA-W-1994/1, Maastricht.

Borghans, L., P. van Eijs, A. de Grip (1994), An Evaluation of Labour Market Forecasts by Type of Education and Occupation for 1992, ROA-R-1994/4E, Maastricht.

Borghans, L., A. de Grip, J. Hoevenberg (1994), De bruikbaarheid van deelmarktinformatie voor het informatiesysteem onderwijs-arbeidsmarkt, ROA-R-1994/13, Maastricht.

Borghans, L., P. van Eijs, W. Smits (1994), Evaluatie arbeidsmarktprognoses naar opleiding en beroep tot 1994, ROA-R-1996/9, Maastricht.

Borghans, L., H. Heijke (1996), Forecasting the Educational Structure of Occupations: A Manpower Requirement Approach with Substitution, in: Labour, Vol. 10, no. 1, pp. 151-192.

Borghans, L., A. de Grip, J. Delmee, J. van Loo, A. Matheeuwsen, W. Smits (1997), Methodiek arbeidsmarktprognoses en - indicatoren 1997-2002, ROA-W-1997/6, Maastricht.

Borghans, L., A. de Grip, H. Heijke (1997), De arbeidsmarkt voor schoolverlaters tot 2002, Economisch Statistische Berichten, nr. 4125, pp. 808-812.

Borghans, L., J. Delmee, P. Marey, J.D. Vlasblom (1998), Toekomstverkenning arbeidsmarkt en scholing tot 2007, Ministerie van Sociale Zaken en Werkgelegenheid, Den Haag. 
Borghans, L., E. Willems (1998), Interpreting Gaps in Manpower Forecasting Models, Labour, Vol. 12, no. 4 , pp. 633-641.

Centraal Planbureau (1999), Centraal Economisch Plan 1999, Sdu, Den Haag.

Eijs, P. van, L. Borghans (1996), The use of RAS in manpower forecasting: a microeconomic approach, in: Economic Modelling, Vol. 13, pp. 257-287.

Eijs, P. van, H. Heijke (2000), Mismatch between Occupation and Education and the Costs and Benefits of Job related Training in: H. Heijke and J. Muysken (eds), Education and Training in a Knowledge-based Economy, Macmillan, Houndsmills/London/New York, pp. 159-189.

Grip, A. de, L. Groot, H. Heijke (1991), Defining Occupational Groupings by Educational Structure, Environment and Planning A, Vol. 23, pp. 59-85.

Grip, A., H. Berendsen, L. Borghans, R. Dekker (1993), Toekomstverkenning leerlingwezen, ROA-R1993/4, Maastricht.

Grip, A., E. Willems, J. Hoevenberg, P. van de Loo, A. Matheeuwsen (1994), Toekomstverkenning arbeidsmarkt zorgsector, ROA-R-1994/6, Maastricht.

Grip, A. de, H. Heijke (1998), Beyond Manpower Planning: ROA's Labour Market Model and its Forecasts to 2002, ROA-W-1998/6E, Maastricht.

Grip, A. de, L. Borghans, W. Smits (1998), 'Future Developments in the Job Level and Domain of High-skilled Workers' in: Hans Heijke and Lex Borghans (eds) Towards a Transparent Labour Market for Educational Decisions, Ashgate, Aldershot/Brookfield USA/Singapore/Sydney, pp. 2156.

Groot, W., H. Maassen van den Brink (1999), Meekijken in de glazen bol van het ROA, Scholar, Amsterdam.

Heijke, H. (ed.) (1994), Forecasting the Labour Market by Occupation and Education, Kluwer Academic Publishers, Boston/Dordrecht/London.

Heijke, H., A. Matheeuwsen, E. Willems (1998), Clustering Educational Categories in a Heterogeneous Labour Market, ROA-RM-1998/2E, Maastricht.

Lucas, R.E. (1976), Econometric Policy Evaluation: A Critique, Carnegie-Rochester Conference Series on Public Policy, no. 1, pp. 19-46.

Matheeuwsen, A., A. de Grip (1997), De doorstroom van het reguliere naar het niet-reguliere onderwijs, ROA-W-1997/4, Maastricht.

McNees, S.K. (1990), The role of judgement in macroeconomic forecasting accuracy, International Journal of Forecasting, Vol. 6, pp. 287-299.

OECD, Employment Outlook 1994, Parijs, 1994.

Researchcentrum voor Onderwijs en Arbeidsmarkt (1994), De arbeidsmarkt naar opleiding en beroep tot 2002, ROA-R-1997/7, Maastricht.

Researchcentrum voor Onderwijs en Arbeidsmarkt (1999), De arbeidsmarkt naar opleiding en beroep tot 2004, ROA-R-1999/8, Maastricht.

Smits, W., B. Diephuis (2000) Evaluatie van de arbeidsmarktprognoses tot 1998 (verschijnt binnenkort). 
Wieling, M., L. Borghans (1997), Aansluitingsproblemen en aanpassingsprocessen op de arbeidsmarkt, Maandschrift Economie, Vol. 61, no. 1, pp. 57-64.

Willems, E., A. de Grip (1993), Forecasting Replacement Demand by Occupation and Education, International Journal of Forecasting, Vol. 9, pp. 173-185. 
Bijlage De Volkskrant 1995 